\title{
Florence Nightingale: Legacy, present and perspectives in COVID-19 pandemic times
}

\author{
Florence Nightingale: Legado, presente e perspectivas em tempos de pandemia da COVID-19 \\ Florence Nightingale: Legado, presente y perspectivas en tiempos de pandemia de COVID-19
}

'Universidade Federal do Rio Grande do Sul. Porto Alegre,

Rio Grande do Sul, Brazil.

"Hospital de Clínicas de Porto Alegre. Porto Alegre,

Rio Grande do Sul, Brazil.

How to cite this article:

Breigeiron MK, Vaccari A, Ribeiro SP. Florence Nightingale:

legacy, present and perspectives in COVID-19 pandemic

times. Rev Bras Enferm. 2021;74(Suppl 1):e20201306.

https://doi.org/10.1590/0034-7167-2020-1306

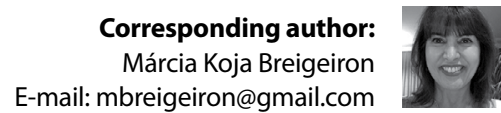

EDITOR IN CHIEF: Dulce Barbosa ASSOCIATE EDITOR: Maria Itayra Padilha

Submission: $08-30-2020$
Approval: 04-02-2021

\section{ABSTRACT}

Objective: Reflect on the influence of Florence Nightingale's teachings to face the COVID-19 pandemic and its repercussions for the future of the profession. Methods: Descriptive reflective study, carried out between May and July 2020, through narrative review on the theme and debates between the authors. Results: The findings are divided into two chapters, namely: Environmental Theory and the teachings of Florence Nightingale in the face of the COVID-19 pandemic; and Florence Nightingale: legacy, present and perspectives. Final considerations: Florence Nightingale's studies with the Environmentalist Theory and her teachings as a nurse are still valid, even after almost two centuries since her prelude, and should continue to serve as a foundation for the consolidation of the nursing profession. Descriptors: History of Nursing; Nurse's Role; Pandemic; Coronavirus; COVID-19.

\section{RESUMO}

Objetivo: Refletir sobre a influência dos ensinamentos de Florence Nightingale para o enfrentamento da pandemia da COVID-19 e suas repercussões ao futuro da profissão. Métodos: Estudo descritivo do tipo reflexivo, realizado entre maio e julho de 2020, por meio de revisão narrativa sobre a temática e debates entre as autoras. Resultados: Os achados estão divididos em dois capítulos, a saber: a Teoria Ambientalista e os ensinamentos de Florence Nightingale diante da pandemia da COVID-19; e Florence Nightingale: legado, presente e perspectivas. Considerações finais: Os estudos de Florence Nightingale com a Teoria Ambientalista e seus ensinamentos como enfermeira ainda são válidos, mesmo depois de quase dois séculos desde seu prelúdio, e devem continuar servindo como alicerce para a consolidação da profissão de enfermagem.

Descritores: História da Enfermagem; Papel do Profissional de Enfermagem; Pandemia; Coronavírus; COVID-19.

\section{RESUMEN}

Objetivo: Reflejar acerca de la influencia de las enseñanzas de Florence Nightingale para el enfrentamiento de la pandemia de COVID-19 y sus repercusiones al futuro de la profesión. Métodos: Estudio descriptivo del tipo reflexivo, realizado entre mayo y julio de 2020, por medio de revisión narrativa acerca de la temática y debates entre las autoras. Resultados: Los hallados están divididos en dos capítulos, a saber: la Teoría Ambientalista y las enseñanzas de Florence Nightingale frente a la pandemia de COVID-19; y Florence Nightingale: legado, presente y perspectivas. Consideraciones finales: Aún los estudios de Florence Nightingale con la Teoría Ambientalista y sus enseñanzas como enfermera son válidos, mismo después de casi dos siglos desde su preludio, y deben continuar sirviendo como base para la consolidación de la profesión de enfermería.

Descriptores: Historia de la Enfermería; Rol de la Enfermera; Pandemia; Coronavirus; COVID-19. 


\section{INTRODUCTION}

Florence Nightingale was included among the 100 women who marked world history and was defined as the most famous nurse of all time ${ }^{(1)}$. In England, her story is taught to children from an early age as one of the great English heroines. It revolutionized care for the sick and, with its actions and precepts, started what we now know as Modern Nursing ${ }^{(1-2)}$. Her projection started in the Crimean War, in 1854(1), where she developed her work, highlighting the way to reorganize nursing, giving visibility not only to the profession, but also to the participation of women in society. At that time, nursing became an institutionalized profession, which demands organized, practical and scientific training ${ }^{(2)}$.

As a nurse, Florence Nightingale presented, in 1859, the Environmental Theory ${ }^{(3)}$, which expresses as the central point the environment, its influence on the human organism and its development, which is capable of favoring or disfavoring the progress of the disease. In this context, the nurse's role is to balance the environment, promoting factors that will contribute to a health-stimulating environment, in order to conserve the patient's vital energy so that he can recover from the disease ${ }^{(3)}$.

Its Environmentalist Theory has an influence on the "doing" of nursing, with indications such as hand hygiene and the environment as a way of not spreading diseases, maintaining physical and mental health as opposed to the disease, organizing work through management protocols, importance of patient-centered care and not in the health-disease process, assistance based on scientific evidence, assistance through quality education and training, importance of patient safety and promotion of care with professional ethics ${ }^{(3)}$.

Nowadays, with the appearance of the new coronavirus, SARSCoV-2, which causes Coronavirus Disease of the year 2019 (Coronavirus Disease-19), better known by its acronym “COVID-19"(4), Florence Nightingale's teachings have become indispensable in combating the pandemic globally, even after more than 160 years of the creation of her theory.

Hand and environment hygiene and social detachment have never been more necessary than they are today, considering not only the severity of COVID-19, but also the contagion and geographic proliferation of the virus. In this perspective, the World Health Organization (WHO) indicates such actions as fundamental for controlling the spread of the new coronavirus ${ }^{(4)}$.

In 2020, the year that we are celebrating the bicentenary of the birth of Florence Nightingale, in addition to recommendations on hygiene, training and organization, she left us as a legacy that nurses are professionals responsible for providing health care and perform teamwork, not subordinated to other professionals, giving visibility to nursing ${ }^{(1-2)}$.

Given this, the present study aims to reflect on the influence of the teachings of Florence Nightingale to face the pandemic of COVID-19 and its repercussions for the future of the profession.

To this end, a reflective descriptive study was carried out between May and August 2020, through a narrative review of the literature and debates between the authors on the subject. The discussion meetings were held in August 2020 through Google Meet ${ }^{\circ}$, and the work was built with the help of an editable document in Google Drive ${ }^{\circ}$, to which all authors had access. Thus, the present manuscript was written synchronously with the support of the online tools already mentioned. From a methodological point of view, this theoretical reflection was structured in two chapters, interconnected from a reflexive perspective. The first, "The Environmentalist Theory and the teachings of Florence Nightingale in the face of the pandemic of COVID-19", presents considerations about the Environmentalist Theory and the teachings of Florence Nightingale in relation to the work of the nursing team during the coping with the pandemic of COVID- 19. The second, "Florence Nightingale: legacy, present and perspectives", consists of a comparative with reflections on its teachings relating its legacy (past) to nursing work in this pandemic moment and the prospects for strengthening the future profession.

\section{THE ENVIRONMENTALIST THEORY AND THE FLORENCE NIGHTINGALE TEACHINGS BEFORE THE COVID-19 PAN- DEMIC}

After analyzing the findings of the narrative review on the Environmentalist Theory and the teachings of Florence Nightingale, we can list ten important and converging dimensions nowadays with the work of the nursing team during the confrontation of COVID-19, namely: hygiene and cleaning; physical and mental health; work organization; social distancing; research, theory and practice; training of professionals; teaching; profession and innovation; profession and leadership; and professional ethics. In this chapter, we will address a reflection on these dimensions worked on by Nightingale and nursing today.

In the "hygiene and cleaning" dimension, the WHO recognizes that the hand washing and hygiene actions, recommended by Florence Nightingale ${ }^{(1-2)}$, are fundamental attitudes to reduce the proliferation of diseases. In view of the COVID-19 pandemic, guidelines on hand washing and antisepsis with $70 \%$ alcohol are being strongly recommended, in addition to preventing mouth, nose and eyes touching, as well as the resumption of respiratory hygiene habits (use the inside of ones arm to cough and sneeze) ${ }^{(4)}$.

In health institutions, in addition to hygiene, strategies were devised to avoid the spread of aerosols in the environment, such as the use of closed suction systems and a face shield, reducing the circulation of visitors - these with restricted hours and only one visit per patient ${ }^{(5)}$. In the prevention of intra-hospital community transmission, the nursing team has a fundamental role, with hand washing and the protection of health professionals and patients, guidelines strengthened daily. Thus, patients who need to be transferred to other health units must be transported with surgical masks, and professionals must use personal protective equipment (PPE) such as caps, N95 masks, goggles or face shield and waterproof aprons to perform procedures on patients ${ }^{(5)}$.

Florence Nightingale also valued the importance of beneficial environments for physical and mental health, as she believed that patients were less likely to improve if they became depressed or anxious ${ }^{(1-3)}$. Thus, maintaining physical and mental health provides awareness and sensitivity to deal with the situation in a calm manner, both for patients and health professionals. Therefore, reading, interacting with others, and practicing physical exercises are important to preserve physical and mental health on days of confinement and after tense days of work. Considering that the 
effects of the pandemic on workers can be long-lasting, leisure activities are recommended for distraction and, mainly, the search for emotional support in this difficult time. Thus, several institutions have been providing free care to professionals, in order to relieve the stress caused by the situation, such as consulting with bioethics, psychology and other mental health professionals ${ }^{(6)}$.

In the "work organization" dimension, Florence Nightingale instituted the first model of nursing care through the systematization of work and defined protocols ${ }^{(1-2)}$. Considering that the new coronavirus causes nonspecific symptoms, such as fever, respiratory and gastrointestinal symptoms, it is interesting to maintain a different flow for symptomatic patients. In view of this, in the present day, protocols formulated by health institutions have been implemented, aiming at their particularities and capabilities. Each institution separates the units into "clean areas" for patients without coronavirus symptoms and "dirty areas" for patients with coronavirus symptoms and, consequently, have different entry points within the same institution ${ }^{(7)}$.

Among the tools that are being implemented on a large scale during the pandemic, which are related to the legacy left by Florence ${ }^{(3)}$, we can mention the isolation, quarantine, social distance and community containment measures. In this regard, precautionary measures, and control of the dissemination of the new coronavirus, when adopted early, have been shown to be effective in slowing the growth rates of COVID-19.

Isolation consists of separating people infected with the disease from people without the virus, in order to protect those who are not infected. Quarantine is one of the most effective means of reducing disease outbreaks and consists of restricting the movement of people who have been exposed to contagious diseases. Social distancing refers to the reduction of interactions between people within the same community, being effective for diseases with transmission from person to person. Examples of consequences of this measure are the closing of schools and remote work. When there is a situation with a greater number of infected individuals, community containment - intervention imposed on the community as a whole - can be thought of, which significantly reduces interactions, aiming at the least possible exposure ${ }^{(8)}$.

In the dimension "research, theory and practice", Florence Nightingale applied her knowledge, using scientific research as an innovative methodology for that time ${ }^{(1)}$, mainly in the scope of public health. After the Crimean War, she created the Rose Diagram, in which petals of blue colors (infectious diseases), roses (war wounds) and black (other causes) represented the reality of the soldiers' deaths, which the vast majority were for hospital infectious diseases, not war wounds. In this way, she was able to visually demonstrate the reduction in deaths after the implementation of her care, when it made it possible for soldiers to have a better chance of survival and understanding this led to changes in the health system in England ${ }^{(9)}$.

It is important to note that public health actions, based on epidemiological research, allow us to identify which are the social determinants involved in community transmission and, also, indicate the main precautionary measures. One aspect of great importance is the involvement of epidemiological surveillance. Large-scale testing for the new coronavirus allows an epidemiological view of the disease, favoring the identification of cases of people with the virus and, thus, reducing community contamination when compatible measures are implemented.

Florence Nightingale defended the importance of well-trained nursing through quality education and, therefore, invested in the education of those women who practice assistance to the sick ${ }^{(1)}$. In this line, which refers to the benefit of training professionals, a study carried out in a hospital in Taiwan emphasizes the importance of implementing a response team in the hospital environment, known as the "Response task force for COVID-19", which has the function of keeping professionals up to date on the epidemic guidelines of the disease, favoring measures to control infection and changes in routines (often daily), as well as carrying out educational measures with health professionals through distance training ${ }^{(7)}$.

In the same logic, another study demonstrated that the training carried out with nurses on topics related to epidemiology, infection control, dressing and removal of personal protective equipment (PPE) was extremely important for the team of nurses to contribute significantly to the screening of suspected patients of COVID-19 and to reduce infection within the hospital environment ${ }^{(5)}$.

Florence Nightingale believed that the teaching of nursing professionals was imperative for the quality of care ${ }^{(2)}$. And, in this moment of crisis that we are going through, many governments are suffering the consequences of the lack of investment in the preparation of professionals to work in pandemic situations and of nursing professionals qualified to work as a workforce ${ }^{(10)}$.

In 2018, the Nursing Now campaign was launched by WHO, together with the International Council of Nurses and other entities, which aims to promote the profession internationally by encouraging the improvement of education, professional development, and conditions of work. work, among other aspects ${ }^{(11)}$. In 2020, the year the campaign ended, but also stipulated by WHO as the international year for nurses and midwives, the lack of professionals to work in the market became evident. In the report of the State of the World's Nursing 2020, they found that, in the world, there are $\mathbf{2 8}$ million nurses working in public and private health sectors, but despite being a large number, there are still 7 million less nurses than the necessary ${ }^{(12)}$. Therefore, it is a priority to use interventions to change this reality, such as: training and qualifying more nurses for a solid workforce; invest in the curriculum, so that they know how to work in public health, in Primary Health Care and in other areas of activity; and training nurses for leadership, not only in the workplace, but also within their community. In addition, in relation to the COVID-19 pandemic, we saw how important a skilled workforce is, requiring many these professionals with qualifications in specific areas, such as in intensive care units ${ }^{(10)}$.

Florence Nightingale instituted nursing as a profession ${ }^{(1)}$, giving visibility to professionals as leaders ${ }^{(1,2)}$ in the care process. Likewise, it innovated when it gave priority to caring for people and not just the health-disease process ${ }^{(1-2)}$. Thus, for 200 years, we have been witnessing the growth of professionalization, training, and competence of nursing in the world. We realized that professionals in this area are important protagonists in the fight against the new coronavirus, because, during the pandemic, nursing teams have been updating and changing their routines, seeking an innovation of care, to reduce the risks of contamination and patient 
mortality ${ }^{(10)}$. Thus, the importance of nurses' clinical knowledge, associated with their care work and their role as a leader, is evident.

During quarantine, in field hospitals and emergency services referred to patients with symptoms of the disease, the nursing team presented itself as the front line, creating strategies to combat the new coronavirus. And, when patients seek hospital care, they are received by trained nurses, who perform the steps of the Nursing Care Systematization, such as collecting patient data, nursing diagnosis and care planning ${ }^{(5)}$. The leadership role of nurses, within the hospital environment, contributes to the supervision of the implementation of protective measures, in the organization of temporary isolation, in an inpatient or intensive care unit and also in rooms for conversations between professionals and family members, with equipment for individual use necessary for worker safety ${ }^{(5)}$.

Florence Nightingale stood out for her professional ethics ${ }^{(1)}$, and, in this pandemic parallel, in which care routines change rapidly, the decisions that nurses make for the conduct with patients are full of uncertainties. Among some ethical issues that affect the nursing team, we have: patient safety; the nurse's own safety and that of his colleagues and families; the allocation of scarce resources; the change in the nurses' relationship with their patients; and the lack and reallocation of professionals to exercise care, often in unknown areas ${ }^{(6)}$.

Related to the safety of professionals, we can attribute their fears to the fact that they work under inadequate conditions, when exercising exhaustive hours, with risk of exposure to the new coronavirus and lacking in number and quality of PPE. In the face of the COVID-19 pandemic, institutions must support workers in decisions to postpone or deny contaminated customer service, as asking professionals to work without the use of necessary safety materials puts their health and that of others at risk. patients and their families, compromising the quality of care. Thus, the dilemma occurs because, on the one hand, there is this risk; but, on the other hand, the professional himself finds it extremely difficult to stop performing patient care, thinking about his responsibilities as a human being and as a health worker, in addition to his oath to relieve suffering and not abandon patients.

Still, the COVID-19 pandemic is demanding application and distribution of resources (these are already scarce) to the service units. This organization of resources is consistent with the implementation of service protocols used in disasters, in order to establish the flow of care and its priorities, which is necessary to balance individual and community needs.

Consequently, the creation of guidelines and protocols with strict criteria to assist in deciding which patients are most likely to benefit during a resource allocation crisis - for example, to use mechanical ventilation devices - are intended to stipulate the best conducts to be taken, as they determine that decisions must be made as a team and not individually by a professional. In addition, in a hostile and inhumane work environment, such as what occurs in the COVID-19 pandemic, nurses are challenged daily to make this space more welcoming, creating strategies for patients to be able to talk to their family members and not feel alone in the situation in which they find themselves ${ }^{(6)}$.

\section{FLORENCE NIGHTINGALE: LEGACY, PRESENT AND PERS- PECTIVES}

The main dimensions of the Environmental Theory and the teachings of Florence Nightingale (legacy) were recovered through narrative review, related to the work of the nursing team during the coping with the pandemic of COVID-19 (present), and brought as more effective and empowering perspectives for nursing work (Chart 1).

Chart 1 - Comparison of Florence Nightingale's teachings in relation to nursing work in the past, present and future

\begin{tabular}{|c|c|c|}
\hline Florence Nightingale Legacy & Present (COVID-19) & Perspectives (Future) \\
\hline $\begin{array}{l}\text { Hygiene and cleaning } \\
\text { Florence Nightingale's main messages } \\
\text { about essential factors in disease } \\
\text { prevention: washing hands with soap and } \\
\text { water; cleanliness of the environment; air } \\
\text { circulation; lighting; hygiene of the sick and } \\
\text { professionals; and house hygiene }{ }^{(1-2)} \text {. }\end{array}$ & $\begin{array}{l}\text { Hygiene and cleaning of hands, surfaces, } \\
\text { clothes, shoes, and alcohol gel are } \\
\text { guidelines that have never been more } \\
\text { important and disseminated by all } \\
\text { professionals. However, although basic, } \\
\text { these principles showed a series of } \\
\text { situations of global fragility. }\end{array}$ & $\begin{array}{l}\text { Hygiene practices have helped to transform public } \\
\text { health concepts and must be maintained by } \\
\text { professionals and the population in general. Basic } \\
\text { hygiene procedures are an indispensable way to } \\
\text { combat microorganisms and must be respected, } \\
\text { reducing the spread of various diseases. }\end{array}$ \\
\hline $\begin{array}{l}\text { Physical and mental health } \\
\text { Florence Nightingale valued the importance } \\
\text { of beneficial environments for mental and } \\
\text { physical health, as she believed that patients } \\
\text { were less likely to improve if they became } \\
\text { depressed or desperate. In Army hospitals, } \\
\text { she encouraged soldiers to read, write letters }_{\text {and talk }}^{(1-3)} \text {. }\end{array}$ & $\begin{array}{l}\text { Maintaining physical and mental health } \\
\text { provides awareness and sensitivity to } \\
\text { deal with the situation in a calm manner. } \\
\text { Therefore, reading, interacting with others } \\
\text { and practicing physical exercises are } \\
\text { important to preserve physical and mental } \\
\text { health in days of social detachment and } \\
\text { work overload. }\end{array}$ & $\begin{array}{l}\text { Thoughts, feelings, and behaviors have a major impact } \\
\text { on the state of physical health. On the other hand, the } \\
\text { state of physical health has a considerable influence on } \\
\text { well-being and mental health. Thus, it is important to } \\
\text { know this link between mental and physical health for } \\
\text { disease prevention. We must work more effectively on } \\
\text { emotional/mental health with the members of our team, } \\
\text { adding professionals with knowledge and experience in } \\
\text { this area. }\end{array}$ \\
\hline $\begin{array}{l}\text { Work Organization } \\
\text { Nightingale instituted the definition of } \\
\text { tasks, service protocols and organization of } \\
\text { professional practice as a work model. With } \\
\text { the implementation of the technical division } \\
\text { of nursing work, he developed the first model } \\
\text { of nursing care through the systematization } \\
\text { of work, in addition to having contributed to } \\
\text { the development of public health }{ }^{(1-2)} \text {. }\end{array}$ & $\begin{array}{l}\text { Protocols are fundamental in the } \\
\text { organization of the care team, with many } \\
\text { nurses being on the front line as responsible } \\
\text { for the development of managerial and care } \\
\text { protocols to combat the pandemic. Thus, } \\
\text { protocols gain greater importance in the } \\
\text { work of everyone, including other health } \\
\text { professions. }\end{array}$ & $\begin{array}{l}\text { The work based on protocols adds qualified and } \\
\text { equitable assistance to patients and provides greater } \\
\text { security not only for them, but also for professionals. } \\
\text { However, as health professionals, we must always } \\
\text { respect the individuality of those we are caring for } \\
\text { and, even working with protocols, always remember } \\
\text { that we deal with people. }\end{array}$ \\
\hline
\end{tabular}

To be continued 


\begin{tabular}{|c|c|c|}
\hline Florence Nightingale Legacy & Present (COVID-19) & Perspectives (Future) \\
\hline $\begin{array}{l}\text { Social distancing } \\
\text { Florence Nightingale, in a period of social } \\
\text { isolation due to an infection (brucellosis), } \\
\text { produced a } 900-\text {-page report on failures in } \\
\text { care during the Crimean War (1853-1856) } \\
\text { and a book on hospital design }{ }^{(3)} \text {. }\end{array}$ & $\begin{array}{l}\text { Around the world, social distancing } \\
\text { initiatives have been instituted to combat } \\
\text { the spread of the new coronavirus. }\end{array}$ & $\begin{array}{l}\text { The social distancing carried out in an organized way } \\
\text { is necessary to reduce the transmissibility of highly } \\
\text { contagious microorganisms, making us rethink our } \\
\text { social coexistence habits. This is a time when many } \\
\text { health professionals take the opportunity to study } \\
\text { about new perspectives of care, such as call centers, } \\
\text { monitoring and health consultancy, which should } \\
\text { have their use improved in the near future. }\end{array}$ \\
\hline $\begin{array}{l}\text { Research, theory and practice } \\
\text { Florence Nightingale aligned the observations } \\
\text { of her work with the teachings received, } \\
\text { testing her ideas and perceptions in practice. } \\
\text { In addition, she created the Rose Diagram } \\
\text { visualize data on contamination, } \text { considered a }^{(1)} \\
\text { revolutionary method for those times }{ }^{(1)} \text {. }\end{array}$ & $\begin{array}{l}\text { The monitoring of statistical data used in } \\
\text { public health has an influence coming from } \\
\text { another great contribution of Florence } \\
\text { Nightingale: the use of graphs to improve } \\
\text { data interpretation. }\end{array}$ & $\begin{array}{l}\text { Professional practice combined with scientific } \\
\text { evidence supports health policies that save lives. }\end{array}$ \\
\hline $\begin{array}{l}\text { Training of professionals } \\
\text { Nightingale defended nursing as a science } \\
\text { that requires training and professional } \\
\text { knowledge }^{(1)} \text {. }\end{array}$ & $\begin{array}{l}\text { Remote training for the use of clinical } \\
\text { protocols aimed at the care of patients and } \\
\text { professionals, within the scope of health } \\
\text { promotion, disease prevention, treatment, } \\
\text { and rehabilitation, is being essential. During } \\
\text { the pandemic, online teaching technologies } \\
\text { were perfected and new technologies } \\
\text { were developed, such as: videos, podcasts, } \\
\text { blogs, infographics, serious games, virtual } \\
\text { meetings and tele-simulation. }\end{array}$ & $\begin{array}{l}\text { Systematic training supports quality care and brings } \\
\text { financial returns to institutions that invest in their } \\
\text { professionals. } \\
\text { The new technologies for training and teaching will } \\
\text { be better consolidated based on the correlation } \\
\text { with innovative/active pedagogical methodologies } \\
\text { and the constant technological development in } \\
\text { education. }\end{array}$ \\
\hline $\begin{array}{l}\text { Teaching } \\
\text { In a society in which only the voices of men } \\
\text { were heard, Florence Nightingale devoted } \\
\text { herself to scientific research and invested } \\
\text { in education. In care, she defended the } \\
\text { importance of well-trained nursing through } \\
\text { quality teaching }\end{array}$ & $\begin{array}{l}\text { Governments need to invest massively } \\
\text { in nursing education, creating jobs, } \\
\text { and promoting the leadership of these } \\
\text { professionals to ensure that there are } \\
\text { enough of them with the right skills for } \\
\text { effective, equitable and sustainable health } \\
\text { systems. }\end{array}$ & $\begin{array}{l}\text { The reflection on the nurse's training process, } \\
\text { regarding the theoretical and practical articulation, } \\
\text { should support the reorientation of doing and } \\
\text { knowing. This reflection needs to be a priority so } \\
\text { that changes can be made in nursing education } \\
\text { and that these are consistent with the needs of the } \\
\text { contemporary world. }\end{array}$ \\
\hline $\begin{array}{l}\text { Profession and innovation } \\
\text { Florence instituted nursing as a profession, } \\
\text { giving visibility to professionals. Likewise, } \\
\text { it innovated when it gave priority to caring } \\
\text { for people and not just the health-disease } \\
\text { process }^{(1)} \text {. }\end{array}$ & $\begin{array}{l}\text { The concepts of health and quality of life are } \\
\text { constantly transformed as innovation and } \\
\text { human complexity change. Nursing teams } \\
\text { around the world have been innovating } \\
\text { for evidence-based care and scientific } \\
\text { knowledge, seeking greater therapeutic } \\
\text { benefit for people with COVID-19. }\end{array}$ & $\begin{array}{l}\text { Florence Nightingale's teachings configure the } \\
\text { bases of nursing care, reinterpreted in the concepts } \\
\text { of person/environment, nursing/professional and } \\
\text { health/disease; and they must continue to support } \\
\text { our profession as well as helping innovation and } \\
\text { entrepreneurship in nursing. }\end{array}$ \\
\hline $\begin{array}{l}\text { Profession and leadership Florence } \\
\text { Nightingale encouraged clinical, care } \\
\text { and administrative leadership; and used } \\
\text { statistical data for hospital reform }{ }^{(1-2)} \text {. }\end{array}$ & $\begin{array}{l}\text { Nursing is playing a fundamental role in } \\
\text { the actions of protection and assistance } \\
\text { to individuals, considering the social } \\
\text { determinants that are involved in the issue } \\
\text { of transmission and increase in the number } \\
\text { of cases of COVID } 19 .\end{array}$ & $\begin{array}{l}\text { Ability to communicate, resolve conflicts and take } \\
\text { initiative are essential leadership attributes for the } \\
\text { nursing profession, which contribute to care. }\end{array}$ \\
\hline 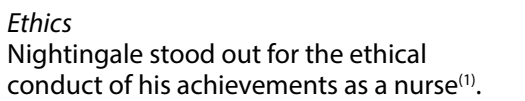 & $\begin{array}{l}\text { Always care for the person we care for and } \\
\text { the ethics of the profession. }\end{array}$ & Provide ethical, scientific, safe and quality assistance. \\
\hline
\end{tabular}

\section{FINAL CONSIDERATIONS}

Florence Nightingale was visionary in her day, offering great contributions in the field of epidemiology. Her studies with the Environmentalist Theory are still valid, even after almost two centuries since her prelude. The procedures described by her, especially hand washing and environmental hygiene, are officially recognized by WHO as strategies to combat the spread of the new coronavirus.

Florence Nightingale's teachings also emphasize that we still need to strengthen nursing in various dimensions of work. And, for the continuation of her legacy, a greater articulation between the teaching and health institutions is necessary, with investment in the valorization of the profession and in the better training of professionals so that we have the advancement of nursing.

Although the study has achieved its objective, there is a limitation regarding the scarcity of research relating the teachings of Florence Nightingale and the work of the nursing team in the face of the COVID-19 pandemic in the Brazilian context.

On the other hand, at the end of this reflection, we can infer that nursing has already learned a lot from Florence Nightingale's journey and that all her teachings are fundamental to coping with COVID-19. Thus, the vast knowledge and experiences of this pandemic moment should solidify and leverage the profession for a future of greater appreciation and strength of the categories. 


\section{REFERENCES}

1. Costa R, Padilha MI, Amante LN, Costa E, Bock LF. O legado de Florence Nightingale: uma viagem no tempo. Texto Contexto Enferm. 2009;18(4):661-9. https://doi.org/10.1590/S0104-07072009000400007

2. Frello AT, Carraro TE. Florence Nightingale's contributions: an integrative review of the literature. Esc Anna Nery. 2013;17(3):573-9. https:// doi.org/10.1590/S1414-81452013000300024

3. Nightingale F. Notas sobre enfermagem: o que é e o que não é. São Paulo: Cortez; 1989.

4. Barjas-Castro ML, Baumgartner JE, Sales LNM, Santos RA, Pereira FB, Castro V. Blood supply strategies facing a reference blood centre in Brazil during the COVID-19 pandemic. ISBT Sci Series. 2020;1-4. https://doi.org/10.1111/voxs.12565

5. Zhang Y. Strengthening the power of nurses in combating COVID-19. J Nurs Manag. 2021;29(3): 357-9. https://doi.org/10.1111/jonm.13023

6. Morley G, Grady C, McCarthy J, Ulrich CM. COVID-19: ethical challenges for nurses. Hastings Center Rep. 2020;50(3):35-39. https://doi. org/10.1002/hast.1110

7. Chang YT, Lin CY, Tsai MJ, Hung CT, Hsu CW, Lu PL, et al. Infection control measures of a Taiwanese hospital to confront the COVID-19 pandemic. Kaohsiung J Med Sci. 2020;36:296-304. https://doi.org/10.1002/kjm2.12228

8. Wilder-Smith A, Freedman DO. Isolation, quarantine, social distancing and community containment: pivotal role for old-style public health measures in the novel coronavirus (2019-nCoV) outbreak. J Travel Med. 2020;1-4. https://doi.org/10.1093/jtm/taaa020

9. Porto F, Costa IZK, Gomes TO, Correia LM, Carrilho NLM, Mercedes Neto. Em tempos da COVID-19: aplicações das lições deixadas por Florence Nightingale. Hist Enferm Rev Eletrôn [Internet]. 2020[cited 2020 Aug 28];11(Especial):64-72. Available from: http://here. abennacional.org.br/here/v11/especial/a8.pdf

10. Williams G. The true worth of a nurse...time to act!. J Adv Nurs. 2020;76(10):2469-70. https://doi.org/10.1111/jan.14418

11. Cassiani SHB, Lira Neto JCG. Nursing Perspectives and the "Nursing Now" Campaign. Rev Bras Enferm. 2018;71(5):2351-2. https://doi. org/10.1590/0034-7167.2018710501

12. World Health Organization (WHO). State of the world's nursing: investing in education, jobs and leadership [Internet]. Geneva: World Health Organization; 2020 [cited 2020 Aug 28]. 117 p. Available from: http//www.who.int/publications/i/item/978924000327 